\title{
ЗАПАДНАЯ ХРИСТИАНСКАЯ ТРАДИЦИЯ В КУЛЬТУРЕ И В ПОВСЕДНЕВНОЙ ЖИЗНИ: ЛЮТЕРАНСКАЯ СЕМЬЯ В ИСТОРИИ РОССИИ ХІХ-ХХ ВВ. (НА ПРИМЕРЕ СЕМЬИ МАТТЕРН)
}

От редакции. В основу статьи В.Я. Швейцера об одном из ярких примеров присутствия лютеранской традиции в России легло выступление автора на международной научнопрактической конференции «Историческая, культурная и социальная роль протестантизма в России и Европе», организованной Центром по изучению проблем религии и общества Института Европы РАН 28 февраля 2019 года. Жанр статьи - исторической семейное исследование рода Мат-терн, однако именно акцент на культуре и этике лютеранства делает эту статью значимой не только и даже не столько в контексте истории, сколько в рамках анализа роли и места западной христианской традиции в России в прошлом и сегодня. Уникальность исследованию придает личная сопричастность автора семейной истории. У повествования две значимых стороны - возрождение представления о живой религиозной традиции русских лютеран (эльзасцев по происхождению) дореволюционного времени и придание импульса дискуссии о западном христианстве в современной России. Обе темы либо забыты, либо освещаются в отрыве от живой лютеранской традиции сегодняшнего дня, что лишает описание современного протестантизма культурных корней. Статья показывает, что, если хорошо поискать, то в русской культуре и в повседневной жизни протестантизм (как, в прочем, и католицизм) тесно переплетены с православием, с развитием российского государства и общества, а не противопоставлены им.

Аннотация. Западная христианская традищия в лище лютеранских общин появилась в России ещё при Иване Грозном. С петровских времён протестантская ветвь христианства стала проявлять себя в жизни России наиболее активно. Лютеранская по вероисповеданию семья Маттерн не только была образцовой с религиозной точки зрения, но и принимала заметное участие в финансовой, юридической, благотворительной, культурной жизни нашей страны. В конще XIX - первой трети XX в. один из Маттернов - Эмиль Эмильевич был известен как видный переводчик и постановщик различных пьес европейских классиков, с успехом шедших на театральных сценах России и СССР. Один из представителей семьи был членом иерковного совета Евангелическо-лютеранского прихода свв. Петра и Павла в Москве, кото-рый активно действует и в настоящее время. Исследование семейной истории, тесно связанной с культурой и этикой протестантской иеркви, является важным элементом анализа места и роли западного христианства в России, как в прошлом, так и в настоящее время.

Ключевые слова: Евангелическо-лютеранская иерковь, мировые судьи, театр, купечество, семья Маттерн.

(C) Швейцер Владимир Яковлевич - доктор исторических наук, главный научный сотрудник, руководитель Отдела социальных и политических исследований Института Европы РАН. Адрес: 125009, Россия, Москва, ул. Моховая, д. 11, стр. 3. E-mail: partsist@list.ru.

DOI: http://dx.doi.org/10.15211/vestnikieran32019125132 
С возрастом стремление узнать историю своих предков занимает особое место в жизни многих людей. Автор также ощутил такую потребность, опубликовав на страницах интернет-издания Фонда "Социальная экология" подробное исследование жизненного пути своей родни, вписавшейся в историю российского и советского общества. Однако ключевое внимание в рамках настоящего исследования будете уделено семейному архиву моей жены Юлии, чей род по материнской линии - Маттерны - был весьма заметен на фоне исторических событий XIX-XX вв.

\section{От Мюлуза до Москвы}

В апреле 1916 г. в московских газетах появились материалы, связанные с 35-летием служебной деятельности известного мирового судьи, действительного статского советника Эмиля Эмильевича Маттерна. Эти статьи и заметки позволяют нам начать биографическое исследование далеко не ординарного московского рода, корни которого, впрочем, лежат много западнее нашей столицы, в Эльзасе. Напомним, что в течение веков эта область регулярно переходила из рук в руки то Франции, то Германии. И жители Эльзаса были, в зависимости от обстоятельств, то онемеченными французами, то офранцузенными немцами. Отметим, что даже фамилия героев нашего рассказа - Маттерн - произносится по-немецки с ударением на "a", а по-французски - с ударением на "e".

Вначале предоставим слово неизвестному нам автору биографии - "В.В.", чей материал и открывает повествование. Он пишет: "Э.Э. Маттерн, москвич, но родился французским подданным, отец его (Э.Ф. Маттерн - В.Ш.) тоже москвич, но был родом из Эльзаса, тогда еще составлявшего одно целое с Францией. Там, в Эльзасе, фамилия Маттерн очень популярна и по-сейчас (так в тексте - В.Ш.). В их роду был со стороны отца один Маттерн, которого церковь, при Константине Великом, причислила к лику святых, и который почитается патроном Эльзаса ${ }^{1 "}$ (В.В.).

Из других источников, найденных в архиве семьи Маттерн, выяснилось, что родовым гнездом этих людей был город Мюлуз, который на некоторых картах обозначен на немецкий лад Мюлльхаузен. Здесь, скорее всего, и познакомились, а позже, в начале XIX века и стали супругами Филипп Маттерн и Анна-Мария Файдельз.

Обстоятельства, при которых эльзасский род Маттерн-Файдельз попал в Россию, достаточно банальны. После прихода к власти Наполеона Бонапарта многие дворянские семьи Франции потянулись за рубеж. Тем более это касалось эльзасцев-лютеран, которые у новых властей вызывали раздражение и своей немецкостью, и евангелическим благочестием, и политической ориентацией на прежнюю королевскую ветвь Бурбонов. Для Маттернов по материнской линии было еще одно отягчающее обстоятельство. Анна-Мария приходилась дальней родственницей знаменитому наполеоновскому маршалу Мортье, и родня явно не одобрила её брак с лютеранином Ф. Маттерном и их отъезд в Россию. Как пишет "В.В.", АннаМария родила свою дочь Юлию в конце 1812 года в Москве, в подвале дома Варгиных, где пряталась от солдат, подчинявшихся Мортье, ставшего в месяцы нашествия наполеоновским губернатором Москвы, и там "разрешилась от бремени" (В.В.). Брат Юлии Эмиль Филиппо-

\footnotetext{
${ }^{1}$ По одной из версий жития св. Матерна, он был учеников апостола Петра и был воскрешен его посохом. По другой версии - в III веке св. Матерн, апостол Эльзаса, основал много церквей и создал церковную организацию. В Страсбурге в Церкви св. Петра Старого сохранилось панно XVI в.: святой Петр, увенчанный тиарой, передает епископский посох епископам Евхариусу (Евхарию) и Валерию (справа показано, как они с помощью этого посоха воскрешают епископа Матернуса (Матерна), сыгравшему большую роль в евангелизации Эльзаса; все трое были учениками апостола Петра).
}

Научно-аналитический вестник ИЕ РАН, 2019, №3 
вич, родившийся в Москве в 1816 году, стал довольно известной фигурой в сообществе московских банкиров. Опять-таки, ссылаясь на В.В., отметим, что Э.Ф. Маттерн "принимал участие в большом банковском деле Ценкер и К. и много лет состоял гласным московской городской Думы". Но обрусению эльзасцев Маттерн препятствовало одно обстоятельство. Вплоть до 1870 г., когда после франко-прусской войны Эльзас был захвачен Германией, Маттерны, как говорилось ранее, считались французскими подданными. Это несколько осложняло их интеграцию в московскую духовную и коммерческую среду. Только после перехода в российское подданство и сам Э.Ф.Маттерн, и его четверо детей - Эмиль, Эдуард, Евгений и Георгий - стали полноправными россиянами, хотя и сохранили свою изначальную принадлежность к евангелическо-лютеранской конфессии. Их бабушка Анна-Мария сохранила своё французское подданство и скончалась в Москве в 1878 году в возрасте 82 лет.

\section{Светское и духовное}

Документы из архива семьи Маттерн свидетельствуют о тесной связи Э.Ф. Маттерна и его супруги Елизаветы Егоровны (урожденной Штекер) с евангелическо-лютеранской общиной Москвы. Они, как и их дети, были усердными прихожанами церкви свв. Петра и Павла в Старосадском переулке. К слову, непонятна позиция нынешней российской власти, почему-то не причисляющей протестантизм к традиционным религиям России (в качестве «традиционных религий» неформально, как правило, политики и общественные деятели перечисляют православие, ислам, иудаизм, буддизм. На эти же религии сделан акцент в преамбуле Закона о свободе совести - Ред.). У данной ветви христианства никак не меньше на это прав, чем, например, у буддистов. В 1878 г. супругам был торжественно вручён памятный адрес в связи с их серебряной свадьбой. В нём, в частности, было сказано: "Глубокоуважаемый дорогой друг и сотрудник! Церковный совет общины Св.Петра и Павла передаёт Вам сердечные поздравления с юбилеем. Вы постоянно вносите большой вклад в работу общины, где все мы трудимся в обстановке совместной радости от нашего общего труда. Вы помогаете нам и словом, и делом, руководствуясь божественными идеями" (Поздравительный адрес 1878. 21 Juni. Silberhochzeitfeier). Другой документ, также поздравительный адрес, был связан с 25-летним юбилеем Э.Ф. Маттерна как члена церковного совета церкви Св. Петра и Павла (1859 - 1884). Эта памятная дата была отмечена следующими словами: "Глубокоуважаемый господин! В день этого значительного события Вашей жизни мы сердечно приветствуем Вас как члена Совета старейшин церкви и его вице-председателя, отдающего все свои силы во благо деяний нашего Бога. Ваши пожертвования и прочая поддержка помогают многим бедным и страдающим обрести уверенность в жизни". Отметим, что Э.Ф. Маттерн был еще членом благотворительного общества при московской городской больнице, о чём свидетельствует отчёт этого общества за 1888 год (Письмо: 21). Он также был, как это вытекает из соответствующих документов архива Маттернов, попечителем фабричного училища Цинделя, хлопотал за некоторых преподавателей этого общеобразовательного заведения.

Благотворительность и сострадание были характерной чертой всей семьи Маттерн. Об этом, в частности, свидетельствуют два документа, адресованных супруге Э.Ф. Маттерна Елизавете Егоровне. В первом из них - Свидетельстве о знаке Красного Креста - дословно сказано следующее: "Главное управление Общества попечения о раненых и больных воинах удостоверяет, что согласно постановлению от 10 июля 1879 г. Высочайше установленный 13 марта 1879 г. знак Красного Креста выдан Елизавете Егоровне Маттерн". Из других документов следует, что в госпиталях, которые опекала Е.Е. Маттерн, находились раненные солдаты и офицеры русско-турецкой войны 1877 - 1878 гг. О благотворительной деятельности 
Е.Е. Маттерн свидетельствует и письмо от председателя распорядительного комитета Общества попечения о неимущих и нуждающихся в защите детях. В нём Е.Е. Маттерн просят, как это было в "прошлые годы, помочь проведению общественного базара для бедных и сирот". Отмечается, что именно Е.Е. Маттерн была достойным организатором такого благодеяния (письмо от 31.01.1888).

Другие документы и артефакты также свидетельствуют о видном месте, которое занимали супруги Маттерн в тогдашнем московском обществе. Сам Э.Ф. был почётным консулом Перу, купцом первой гильдии, вел свои торговые дела не только в Москве. Но и в Нижнем Новгороде, и, как уже говорилось, был гласным Московской Думы. Похороны Э.Ф. Маттерна в 1889 г. стали событием городского масштаба. В частности, в них принял участие тогдашний генерал-губернатор Москвы князь Долгоруков. Его визитка "Генерал-адьютант князь Долгоруков, член Государственного Совета, московский генерал-губернатор" также имеется в архиве.

\section{Дом на Рождественском бульваре}

Среди визиток, сохранившихся в архиве семьи Маттерн, обращает на себя внимание скромный квадрат картона "Сергей Владимирович Алексеев". Это своего рода символ интересов и профессиональных, и житейских, которые тесно связывали семью Маттерн с московской жизнью. Ведь С.В. Алексеев - один из видных московских купцов - был, как известно, отцом К.С. Станиславского (Алексеева). И знаком он был с семьёй Маттернов не только по купеческим интересам, но прежде всего в связи с участием сына Э.Ф. Маттерна - Эмиля - в театральной жизни Москвы.

Опять предоставим слово "В.В.", отмечавшего различные грани талантов семьи Маттерн. В своём очерке автор упоминает дом на Рождественском бульваре, 14, который с 60-х годов XIX в. принадлежал Маттернам. Заметим, что вплоть до последнего времени вензель "ЭМ" венчал это сооружение. "В.В." пишет об этом доме следующее: "В доме Маттернов на Рождественском бульваре был небольшой, но постоянный и прекрасно оборудованный театр с довольно большой сценой и зрительным залом. В своё время этот дом считался одним из самых популярных в Москве. В нём часто устраивались литературные вечера и концерты, потому что семья Маттерн охотно уступала свою сцену и зрительный зал для безвозмездного пользования благотворительным обществам разного рода. В силу этого семья Маттерн всегда поддерживала тесную связь с артистическим и художественным миром... Во время частных спектаклей в домашнем театре играла преимущественно молодёжь. Но это был не любительский дилетантизм, а искусство...» ("В.В.").

В доме Маттернов имелась прекрасная библиотека, и её также могли использовать не только хозяева дома и их родственники, но и более широкий круг читателей. Дом на Рождественском бульваре являлся и своеобразной картинной галереей, всего коллекция насчитывала более 300 картин. Стены здесь были увешаны полотнами как известных российских и иностранных художников, так и начинающих живописцев. Семья Маттерн для поощрения последних покупала у них картины с единственной целью - материально поддержать молодые дарования.

Неудивительно, что в обстановке человеколюбия, искренней благотворительности, поклонения искусству воспитывались и дети Маттернов. Религиозный дух лютераневангелистов, которым были пронизаны все поступки родителей, безусловно способствовал формированию у детей соответствующих жизненных принципов. Среди детей Э.Ф. Маттерна (все они, как и их родители, покоятся в семейном захоронении на Введенском (б. Немец- 
ком) кладбище) особую известность приобрёл уже упоминавшийся Эмиль Эмильевич Маттерн. Отметим, что его жизненный путь (1854 - 1938 гг.) связал две, казалось бы, несовместимые эпохи - закат имперской России и становление советского государства.

\section{Карьера мирового судьи}

Если открыть какие-либо справочники об известных москвичах начала XX века, то информация об Э.Э. Маттерне в основном будет касаться его деятельности как мирового судьи, через руки которого прошло множество, говоря современным языком, резонансных дел. Правда, на юридическую стезю Э.Э. Маттерн пришёл не сразу. Вначале он по собственной инициативе поступил на математическое отделение МГУ, но вскоре решил продолжить учёбу в Институте путей сообщения (рукопись 17). Учёбе помешала русско-турецкая война и призыв в качестве офицера-кавалериста на действительную воинскую службу. Однако уже в конце 1870-х гг. демобилизовался и поступил на юридический факультет СанктПетербургского университета. Получив диплом юриста, Э.Э. Маттерн вернулся в родную Москву и в течение 35 лет служил идеалом права в качестве мирового судьи. В 1881-1916 гг. он постоянно избирался на эту престижную в те времена должность и был последовательно мировым судьёй всех округов центра Москвы. По юридической стезе - правда, как адвокат пошёл и другой сын Э.Ф. Маттерна, Евгений. Последний в начале XX в. даже попытался стать одним из лидеров московской организации Союза октябристов, однако его политической карьере мешали явно антисемитские взгляды, абсолютно нехарактерные для других Маттернов ("Голос Москвы", 1912 г.). Вплоть до революции октября 1917 года присяжным поверенным был и другой Маттерн - Эдуард.

В воспоминаниях современников отмечается, что Э.Э. Маттерн постоянно отстаивал интересы закона, не шёл ни на какие сделки с совестью. Среди московских юристов он первым обратил внимание на детскую преступность и выдвинул идею "ювенальных судов", которая была поддержана в городской Думе. Он также считал необходимым привлекать учащихся гимназий к обсуждению интересующих их проблем и получил в этом вопросе поддержку других мировых судей (Доклад №126 Мосгоруправы). Эмиль Эмильевич постоянно работал над вопросами народного просвещения, считал необходимым создание начальных школ для детей из, как бы сегодня сказали, неблагополучных семей. Маттерн руководствовался в своих поступках не только буквой закона и христианской моралью, но и простой человеческой добротой.

Вот показательный пример. В мае 1916 года он обратился в Совет дома призрения им. братьев Боевых. Дома призрения были тогда главным инструментом в системе социального обеспечения. Маттерн ходатайствовал за "безземельных крестьян" супругов Петровых, которых необходимо было поместить в Дом призрения, ибо у них не было никаких средств для самостоятельного существования (Прошение Э.Э. Маттерна от 4 мая 1916 года). Показательно, что именно простых крестьян он выбрал в качестве свидетелей составленного им духовного завещания. Из этого документа следовало, что мировой судья был далеко не бедным человеком - владельцем ряда домов на Краснопрудной улице (фамильный дом на Рождественском бульваре, о котором ранее шла речь, был продан в 1910 г., а на полученные средства братья Эмиль, Эдуард и Евгений смогли приобрести собственное жилье). Кстати, одной из сторон, указанных в завещании, была супруга Эмиля, Юлия Петровна Бирсгалс, происходившая из известного рода прибалтийских дворян (латышей). Завершая эту тему, отметим, что Э.Э. Маттерн пережил всех своих братьев, а Ю.П. Маттерн, прабабушка моей жены 
Юлии, умерла в 1942 г. Последней носительницей фамилии Маттерн была его дочь Елизавета Эмильевна, скончавшаяся в 1973 г.

В работе мирового судьи Э.Э. Маттерна была и еще одна, внешне малозаметная сторона профессиональной деятельности. К нему постоянно обращались актёры многих московских театров, а также художники с различными ходатайствами, касавшимися их профессиональной деятельности, имущественных споров с владельцами театров и картинных галерей. Во многих случаях Маттерну удавалось добиться от присяжных поверенных в судах Москвы решений в пользу служителей Мельпомены (рукопись биографии Э.Э. Маттерна).

\section{В свете рампы двух эпох}

Карьера Маттерна на поприще мирового судьи окончилась с упразднением этой юридической категории после Октябрьской революции 1917 года. Неизвестный автор в рукописной биографии Э.Э. так описывает этот значительный эпизод в жизни нашего героя: "Революционный переворот застал его в должности судьи Лубянского участка. Судьям, под давлением новых властей, пришлось прекратить свою работу" (рукописная запись 1918 г.). Однако неоспоримый авторитет Э.Э. Маттерна как кристально честного человека, борца за справедливость и милосердие дал ему своеобразный "карт-бланш" и у новых властей. Об этом вполне наглядно свидетельствует документ (удостоверение), выданный Э.Э. народным комиссариатом социального обеспечения 26 октября 1918 г. Из него следует, что Маттерн после революционных событий 1917 г. был назначен и.о. инспектора РевизионноИнспекторского управления по продовольственным делам, которому поручалось "произвести ревизию продовольственного дела в Отделе Социального Обеспечения г. Москвы, в детских домах и богадельнях, подведомственных НКСО" (РСФСР, НКСО, 26.Х.1918 г.).

Молодая советская власть использовала и другое направление его бывшей профессиональной деятельности. В начале 20 -х гг. он по просьбе Моссовета стал одним из пионеров борьбы с детской беспризорностью, обращая особое внимание на содержание малолетних преступников в тюрьмах. Он требовал для них создания человеческих условий в камерах, обращал внимание на антисанитарию и категорически возражал против совмещения в одних камерах малолеток и матёрых уголовников, прекрасно представляя, к каким последствиям приведёт это "сожительство".

Неоспоримо и его активное участие в театральной жизни Москвы. Театр всегда был второй (а может быть и первой) любовью этого замечательного человека. В 1921 г. он был принят в профсоюз работников издательств, что в период гонения на всех "бывших", а действительный статский советник Э.Э. Маттерн таковым и являлся, было событием крайне редким. Причём в профбилете в графе "профессия" чётко указано "переводчик, драматург" (членский билет Э. Маттерна). Впоследствии он был принят и в Союз Советских писателей (секция драматургов). В архиве Маттерна имеются его статьи, посвящённые, в частности, творчеству А.Н. Островского.

Однако вернёмся к истокам его увлечения театром. В 1916 г. в период торжеств в связи с 35-летием юридической деятельности он поделился с читателями ориентированного на культурную часть московской общественности журнала "Рампа и жизнь" (1916, №14, 3 апреля, с.5) следующими воспоминаниями: "Еще студентом я начал увлекаться театром. В качестве любителя я выступал во многих спектаклях, устраиваемых в Благородном собрании, Славянском базаре и т.п. Увлечение театром помогло мне быстро завести знакомство со многими артистами Малого театра. Вскоре я начал переводить сначала одноактные, а затем и большие драматические произведения... Невзирая на то, что служба мирового судьи отнима- 
ла у меня массу времени... я, тем не менее, не бросал работать для театра, следя за всеми выдающимися произведениями Запада, продолжал делать для театра переводы... Всего я перевел более 150 пьес А.Доде, М.Меттерлинка, Г.Гауптмана, Г.Ибсена, А.Дюма. Переведённые мною лично или в соавторстве пьесы шли как в Малом театре, так и во МХАТе" ("Рампа и жизнь", 1916, №14, с.5-6). Некоторые из указанных пьес до сих пор идут в ведущих театрах России. Отметим, что на обложке этого журнала с материалами о Маттерне был помещён и портрет Эмиля Эмильевича со словами "К 35-летию судебной, литературной и общественной деятельности". Говоря о Маттерне как о человеке, настоящем русском интеллигенте и большом знатоке театральной жизни, нельзя не привести стихи основателя цирковой династии Дуровых - Анатолия Леонидовича, которые он адресовал Маттерну, даря ему свою книгу "В жизни и на арене" (Воронеж, 1914, в трёх частях). "В досуг минут моих свободных, я вник в тождественность идей. Всегда смирял я зло животных, а Вы смиряли зло людей". Весьма показателен и отзыв о Маттерне великого Станиславского (в 1928 г.), с которым он был близко знаком еще с 80-х гг. XIX в.: "Я знаю Маттерна с самых юных лет, знаю как человека, который неустанно и разносторонне работал в течение всей своей жизни, продолжает работать и сейчас, несмотря на его преклонный возраст... Пьесы в его переводах, написанные всегда литературным языком, ставились на сцене "Общества искусства и литературы" и затем и на сцене МХАТ" (Советская культура).

Процитированные слова классика отечественного театра были включены в некролог в связи с кончиной Э.Э. Маттерна (16.09.1938 г.), последовавшей спустя полтора месяца после ухода из жизни самого К.С. Станиславского. От себя замечу, что для редакторов "Советской культуры" было весьма рискованно откликнуться некрологом такого содержания на смерть человека, не только никогда не состоявшего в партии большевиков, но и являвшегося представителем буржуазной и религиозной среды иностранного происхождения. Именно гуманизм и человеколюбие в сочетании с высоким профессионализмом были характерными чертами всех представителей рода Маттерн, чья деятельность на разных этапах непростой истории нашей родины сделали их частью, и весьма достойной, исторического наследия России. История семьи Маттерн подтверждает важный вклад европейцев в экономику, культуру и общественную жизнь России.

\section{Источники и литература}

В.В. Семья Маттерн. Вечерний курьер. Москва, 01.04.1916, №573.

Некролог о Е.Э. Маттерне. Голос Москвы, 1912, №280.

Некролог о Э.Э. Маттерне. Советская Культура, 18.09.1938.

Союз Советских писателей СССР. Правление 20.12.1934.

Э.Э. Маттерн. Билет члена профсоюза работников издательств №031509, 1934.

Удостоверение НКСО РСФСР от 26.10.1918.

Э. Маттерн. Островский и народный театр в Москве. Театральный курьер, №29, 20.10.1918.

Э. Маттерн. А.Н. Островский и Общество русских драматических писателей и оперных композиторов. В кн.: Островский к 100-летию со дня рождения. М., 1923. С. 47-55.

Юбилей Э.Э. Маттерна. Рампа и жизнь, №14, 03.04.1916. С. 5-6.

Доклад №126 Московской городской управы, 30.10.1910. С. 3; Доклад №396, 29.10.1910. C. 2,3 .

Отчёт благотворительного общества при московской городской больнице за 1888. С. 21. 
В Совет дома призрения имени братьев Боевых. Прошение от мирового судьи Лубянского участка Э.Э. Маттерна.

Духовное завещание Э.Э. Маттерна от 31.05.1916.

Письмо от председателя распорядительного комитета Общества попечения на имя Е.Е. Маттерн от 31.01.1888 №22.

Свидетельство от Главного управления Общества попечения на имя Е.Е. Маттерн. СПб, 31.07.1879.

Из студенческих воспоминаний Э.Э. Маттерна. Рукописный дневник. С. 1-9.

Рукописная биография Э.Э. Маттерна. Автор неизвестен.

Рукописный список переводов пьес и романов Э.Э. Маттерна, созданных с 1883 г. Автор неизвестен.

Духовное завещание А.М. Файдельс (Маттерн) от 1876 г. (на нем.яз.).

Поздравительный адрес от церковного совета евангелическо-лютеранской церкви Св. Петра и Павла, 21.06.1878 (на нем.яз.).

Поздравительный адрес от церковного совета евангелическо-лютеранской церкви Св. Петра и Павла, декабрь 1884 (на нем. яз.).

\section{The Western Christian Tradition in a Culture and in a Daily Life: the Lutheran Family in Russian History of XIX-XX cent. (on the example of the Mattern's family)}

Author. Vladimir Schweitzer, Doctor of Sciences (History), Head of Department for Social and Political Research, Institute of Europe, Russian Academy of Sciences. Address: 11-3 Mokhovaya str., Moscow, Russia, 125009. E-mail: partsist@list.ru.

Abstract. The representatives of the Evangelical Lutheran appeared in Russia in the times of the Ivan the Terrible. Since the times of Peter the Great, the Lutheran branch of Christianity actively manifested itself in the life of Russia. The Lutheran tradition of the Mattern family was not only exemplary from a religious point of view, but also prominently participated in the financial, legal, charitable, cultural life of our country. From the end of XIX century to the end of the first third of the XX century, one of the Matterns, Emil Emilievich, was known as a prominent translator and director of various plays of European classics, which have been successfully staged in theatres of both Russia and the USSR. One of Matterns was a member of the church council in a Lutheran parish of the St. Peter and Paul in Moscow that continue its activities nowadays. The daily history is a personal but important element of the analysis of the westerm culture and ethics on Russian ground in the past and in present time. family.

Keywords: Lutheran Evangelical Church, magistrates, theatre, merchant class, the Mattern

DOI: http://dx.doi.org/10.15211/vestnikieran32019125132 